\title{
Effects of climate and land use on landscape soil respiration in northern Wisconsin, USA: 1972 to 2001
}

\author{
Daolan Zheng ${ }^{1, *}$, Jiquan Chen ${ }^{1}$, Asko Noormets ${ }^{1}$, Eugénie S. Euskirchen ${ }^{2}$, \\ James Le Moine ${ }^{1}$
}

${ }^{1}$ Department of Earth, Ecological, and Environmental Sciences, The University of Toledo, Toledo, Ohio 43606, USA

${ }^{2}$ Institute of Arctic Biology, University of Alaska Fairbanks, Fairbanks, Alaska 99775, USA

\begin{abstract}
Changes in climate and land use affect soil respiration rates (SRR) significantly, but studies of these effects across entire landscapes are rare. We simulated responses of landscape mean SRR (LMSRR) to such changes from May to October over a 30 yr period in a managed, predominantly forested landscape in northern Wisconsin, USA, using: (1) 6 satellite-derived land-cover maps (1972, $1978,1982,1987,1992$, and 2001); (2) monthly air temperature data in the corresponding years of the cover maps; and (3) SRR models driven by soil temperature $\left(T_{\mathrm{s}}\right)$ at $5 \mathrm{~cm}$ depth. LMSRR seemed to increase linearly by $77 \%$ from 0.625 in May to $1.104 \mathrm{~g} \mathrm{CO}_{2} \mathrm{~m}^{-2} \mathrm{~h}^{-1}$ in July, and then decreased at an increasing rate to $0.411 \mathrm{~g} \mathrm{CO}_{2} \mathrm{~m}^{-2} \mathrm{~h}^{-1}$ in October. LMSRR was more sensitive to an increase of minimum temperature than that of mean or maximum temperature, suggesting that future climate change might impact SRR in high-latitude forests more than other biomes. LMSRR in September over the study period was similar to that of June but with $92 \%$ higher variation, while both landscape mean air temperature and precipitation in September had lower variation than in June. This indicates that the topsoil layer functions differently during soil warming and cooling phases. Changes in land cover composition from 1972 to 2001 increased LMSRR by 2.8 to $3.1 \%$ while $2{ }^{\circ} \mathrm{C}$ differences in growing season mean air temperature increased the SRR by 6.7 to $7.0 \%$. The combined effects of both variables on the SRR are more complex, varying from 3.8 to $10.0 \%$.
\end{abstract}

KEY WORDS: Landscape-scale soil respiration · Temperature variation · Landscape composition • Empirical model · Carbon flux

\section{INTRODUCTION}

$\mathrm{CO}_{2}$ is produced in soils by roots and the microorganisms responsible for decomposition. While root respiration varies with productivity and root allocation depending on vegetation types (Jackson et al. 1996, Hogberg et al. 2001, Giardina \& Ryan 2002), activities of microorganisms such as bacteria and fungi are linked to the decomposition of soil organic matter associated with litter quality and quantity and nutrient availability (Berg et al. 1987, Magill \& Aber 1998, Carreiro et al. 2000). Such belowground processes are controlled by both abiotic and biotic factors, and are therefore related to climate change and land use dynamics (Raich \& Schlesinger 1992, Jackson et al. 2000, Ogle et al. 2003). Soil respiration (SR) is a necessary component in quantifying ecosystem carbon sources/sinks and plays an important role in global carbon cycling (Tans et al. 1990, Field et al. 1992, Dixon et al. 1994, Ciais et al. 1995, Grace et al. 1995). Global warming in the north temperate zone (Keeling et al. 1996, Nicholls et al. 1996), on the one hand, could enhance the terrestrial $\mathrm{CO}_{2}$ uptake in Northern Hemisphere (Fan et al. 1998, Rayner et al. 1999). On the other hand, warming might also have reduced the $\mathrm{CO}_{2}$ uptake by increasing decomposition (Dai \& Fung 1993, 
Goulden et al. 1998). Recent flux measurements at individual high-latitude sites suggest that, at least in the short term, any direct effect of warming on net primary production may be more than offset by an increase in soil respiration caused by global warming.

Land clearing and combustion of fossil fuels are 2 major causes for elevating atmospheric $\mathrm{CO}_{2}$ concentrations from 280 to $>360$ ppm in the last $200 \mathrm{yr}$ (Keeling et al. 1995). Various models have predicted that the total amount of carbon released annually to the atmosphere increases with the global deforestation rate (Alcamo et al. 1996, Yamagata \& Alexandrov 1999). Twenty percent of existing forests and woodlands have been logged and/or converted to other uses worldwide since the pre-industrial era (Richards 1991). Turner et al. (1996) calculated that $45 \%$ of the potential forest cover of the continental USA had been converted to other land cover types. A recent study suggested that both changes in land use and climate contributed to carbon dynamics of the ecosystems in the US (Schimel et al. 2000).

Despite the importance of SR in the carbon budget at various spatial and temporal scales, and numerous ecosystem- and global-level studies on SR (Raich \& Schlesinger 1992, Howard \& Howard 1993, Lloyd \& Taylor 1994, Raich \& Potter 1995, Thierron \& Laudelot 1996, Potter \& Klooster 1998, Raich et al. 2002, Ma et al. 2004), little effort has been made to understand how changes in temperature and land use could affect SR rates (SRR) for an entire landscape. Analyses of the interactions between changes in temperature and land-cover mosaic on landscape mean SRR (LMSRR) are even more rare. Studies pertaining to differences

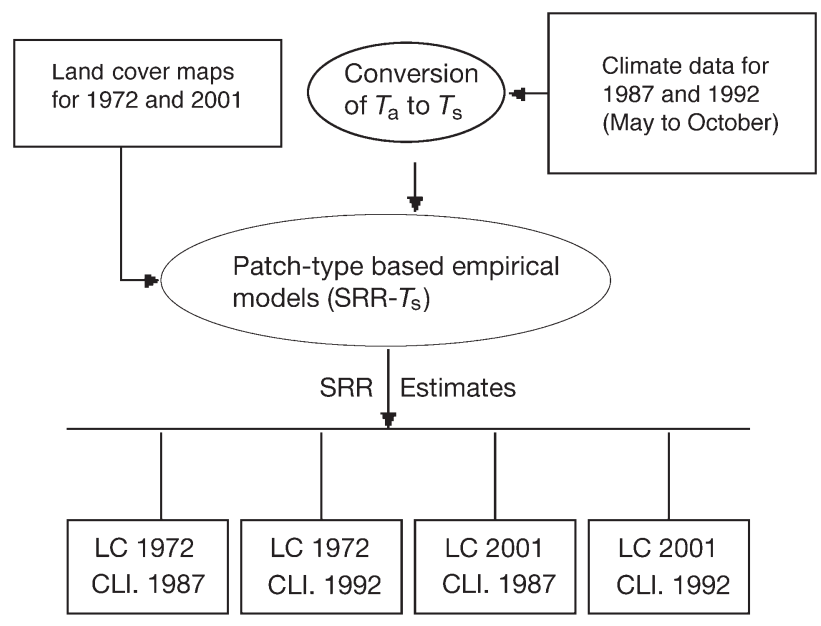

Fig. 1. Flowchart of the framework. Air temperature data $\left(T_{a}\right)$ obtained from the NOAA were indirectly converted to soil temperatures $\left(T_{\mathrm{s}}\right)$ at the $5 \mathrm{~cm}$ depth using regressions developed from field observations. SRR: soil respiration rates; SRR- $T_{\mathrm{s}}$ : SRR soil temperatures; LC: land cover; CLI.: climate in SRR among the various patch types that comprise a managed landscape can provide information to land managers, helping them to understand how landscape SR is altered by human-induced disturbances such as timber harvest and increases in the proportion of young forests under climate change.

The landscape-scale study defined in this research is in an area that contains spatially heterogeneous ecosystems, ranging in size from a few square kilometers to hundreds of square kilometers in a grid format. This study is designed to evaluate how growing season LMSRR respond to changes in monthly mean soil temperature and land cover at an inter-annual scale in a managed forest landscape over 3 decades. This study addresses 3 specific questions: (1) What are the relative effects of temperature and land cover changes on SRR across the landscape? (2) How does the seasonal trend in LMSRR vary interannually as a function of soil temperature? (3) What are the implications of the seasonal variation in soil temperature for regional and global SRR and carbon budgets?

\section{METHODS}

We used 'real' landscapes of 1972 and 2001 in Chequamegon National Forest, USA, derived from remote sensing data. We combined these data with publicly accessed climate data in 1987 and 1992 provided by the National Oceanic and Atmospheric Administration (NOAA) web site to examine effects of changes in land use and climate on LMSRR using patch-type based SRR-soil temperature (SRR- $T_{\mathrm{s}}$ ) empirical models (Fig. 1).

\subsection{Study area}

The Chequamegon National Forest (about 39000 ha) is located in the Washburn Ranger District of northern Wisconsin, USA $\left(46^{\circ} 30^{\prime}-46^{\circ} 45^{\prime} \mathrm{N}, 91^{\circ} 02^{\prime}-91^{\circ} 22^{\prime} \mathrm{W}\right)$, where extensive research on biodiversity, microclimate, carbon and water cycles, and edge effects has been conducted since 1994 (Gustafson \& Crow 1996, Chen et al. 1999, Saunders et al. 1999, Zheng \& Chen 2000, Brosofske et al. 2001, Euskirchen et al. 2001, 2002, Watkins et al. 2003). The area experienced dramatic changes in land-use patterns characterized as increases in timber harvest and proportion of young growth between 1972 and 2001 (Bresee et al. 2004). The geology is characterized by Precambrian shield bedrock and a late Wisconsin-age glaciated landscape. The topography is flat to rolling with elevations ranging from 232 to $459 \mathrm{~m}$. Terraces and pitted outwash landforms are composed of deep, coarse-textured soils. 
The climate is characterized by a short/hot summer with a growing season of 120 to $140 \mathrm{~d}$ and cold winters. Long-term monthly mean temperature from December to February in a 30 yr period (1971 to 2000) is $-10^{\circ} \mathrm{C}$ in Ashland, Wisconson (http://mcc.sws.uiuc. edu/Temp/WI/470349_tsum.html), about $20 \mathrm{~km}$ southeast of the geographic center of the Chequamegon National Forest. Annual precipitation ranges from 660 to $700 \mathrm{~mm}$ (Albert 1995). Forests accounted for about $83 \%$ of the study area in 2001 dominated by the Temperate Mixed Forests.

Six land-cover maps and climatic data sets in the corresponding years over a $30 \mathrm{yr}$ period, and field data on $T_{\mathrm{s}}, \mathrm{SR}$, and other meteorological data in the landscape since 2001 were developed, constructed, or collected (Noormets et al. unpubl.). These data allow us to quantify relationships between air temperature $\left(T_{\mathrm{a}}\right)$ and $T_{\mathrm{s}}$ and between $T_{\mathrm{s}}$ and SRR.

\subsection{Land-cover maps}

Multi-year land-cover maps from 1972 to 2001 derived from satellite data (Landsat Multispectral Scanner [MSS] and Thematic Mapper [TM]) for the study area at approximate 5 yr intervals except between 1992 and $2001(1972,1978,1982,1987,1992,2001)$ by Bresee et al. (2004) were used in this study. Six major cover types were identified in these maps: hardwood (HW), mixed hardwood/conifer (MIX), regenerating forest/shrub (RFS, hereafter referred to as young growth, YG), jack pine (JP), red pine (RP), and non-forested bare ground (NFBG, hereafter referred as NF). A supervised maximum likelihood classification scheme was initially conducted using spectral training sets, based on known stands of each cover type. Histograms were created for each cover type using the threshold tool in ERDAS IMAGINE (ERDAS 1999). Cover types were determined based on the spectral distance between the class signatures. Identification between forested and nonforested cover types was a relatively straightforward process, while separation among the forested cover types was more difficult and required additional image processing techniques (Bresee et al. 2004). The overall accuracy for all images and cover types was about $80 \%$. We resampled all pixels to a standard $60 \mathrm{~m}$ resolution for landscape-scale analysis.

\subsection{Climate data}

We examined the LMSRR from May to October (hereafter referred as the growing season), although this is slightly longer than actual growing days in the study area (Albert 1995). We chose this time period for
3 reasons: (1) $T_{\mathrm{a}}$ were available at a monthly time step; (2) SRR- $T_{\mathrm{S}}$ relationships were established based on the data collected during this period; and (3) summer SR constitutes the majority of annual SR. Studies at similar latitudes indicated that SR in temperate mixed HW and MIX forests during the period accounted for about 70 to $78 \%$ of annual SR (Davidson et al. 1998, Janssens et al. 2000).

Monthly minimum and maximum air temperature ( $T_{\min }$ and $T_{\max }{ }^{\circ} \mathrm{C}$ ) during the growing seasons of the 6 years corresponding to the land-cover maps (1972, 1978, 1982, 1987, 1992, and 2001) were obtained from the NOAA (ftp://ftp.ncdc.noaa.gov/pub/data/ prism100). Monthly mean temperatures were derived from averaging $T_{\min }$ and $T_{\max }$. We used 1987 and 1992 climatic data to illustrate how climate change could affect LMSRR for 2 reasons: (1) they showed the maximum difference $\left(15.4^{\circ} \mathrm{C}\right.$ in 1987 vs. $13.4^{\circ} \mathrm{C}$ in 1992) in landscape growing season mean temperatures among the 6 years over the $30 \mathrm{yr}$ study period; and (2) the $2^{\circ} \mathrm{C}$ difference was approximately in the middle range of the 0.8 to $3.5^{\circ} \mathrm{C}$ global mean temperature increase by the year 2100 predicted by general circulation models developed independently in many countries (Stocks et al. 2000). Furthermore, the growing season means of these 2 years were symmetrically distributed from the $14.4^{\circ} \mathrm{C}$, a $30 \mathrm{yr}$ mean growing season $T_{\mathrm{a}}$ (1971 to 2000) in the landscape. The original temperature data with $4 \mathrm{~km}$ spatial resolution were resampled to $60 \mathrm{~m}$ resolution to match the resolution of land-cover maps for the simulations.

\subsection{Soil temperature estimation and validation}

$T_{\mathrm{a}}\left({ }^{\circ} \mathrm{C}\right)$ at $1.5 \mathrm{~m}$ and soil temperatures at $10 \mathrm{~cm}$ depth $\left(T_{\mathrm{s} 10},{ }^{\circ} \mathrm{C}\right)$ were simultaneously collected during the 2002 growing season from meteorological stations in HW, RP, and YG forest stands. The $T_{\mathrm{a}}$ was measured with HMP45AC probes (Vaisala) and $T_{\mathrm{s} 10}$ recorded using soil CS107 temperature probes (Campbell Scientific, CSI). Both variables were sampled every $20 \mathrm{~s}$ and the half-hour averages were stored in CR10 data loggers (CSI). Daily mean $T_{\mathrm{a}}$ and $T_{\mathrm{s} 10}$ were then calculated by establishing regression models between the 2 variables. Previous studies at regional and continental scales have suggested that daily $T_{\mathrm{s}}$ at the top layers are correlated linearly with $T_{\mathrm{a}}$ of the previous day with some degree of time lag (Zheng et al. 1993, Brown et al. 2000). We used $T_{\mathrm{s}}$ and $T_{\mathrm{a}}$ observations on the same day to establish the linear models to convert $T_{\mathrm{a}}$ to $T_{\mathrm{s}}$. This may not provide the best fit, but it is practical and necessary for this study because the actual $T_{\mathrm{a}}$ inputs for the entire landscape that were available to us are monthly daily means, and therefore the time lag was not be discernible in the data. 
Table 1. Regression equations used for converting monthly air temperatures $\left(T_{\mathrm{a}},{ }^{\circ} \mathrm{C}\right)$ to soil temperatures at $10 \mathrm{~cm}$ depths $\left(T_{\mathrm{s} 10,}{ }^{\circ} \mathrm{C}\right)$ based on field observations from May to October for 3 cover types in Chequamegon National Forest: HW, hardwood; RP, red pine; YG, young growth. SE: standard error

\begin{tabular}{|c|c|c|c|c|c|c|}
\hline $\begin{array}{l}\text { Cover } \\
\text { type }\end{array}$ & Month & Equation & $\mathrm{r}^{2}$ & $\mathrm{~N}$ & $\mathrm{p}$ & $\mathrm{SE}\left({ }^{\circ} \mathrm{C}\right)$ \\
\hline HW & May & $T_{\mathrm{s} 10}=0.40 T_{\mathrm{a}}+3.3$ & 0.77 & 31 & 0.001 & 1.3 \\
\hline HW & Jun & $T_{\mathrm{s} 10}=0.46 T_{\mathrm{a}}+5.9$ & 0.79 & 30 & 0.001 & 1.3 \\
\hline HW & Jul & $T_{\mathrm{s} 10}=0.24 T_{\mathrm{a}}+13.0$ & 0.25 & 29 & 0.01 & 1.0 \\
\hline HW & Aug & $T_{\mathrm{s} 10}=0.36 T_{\mathrm{a}}+10.4$ & 0.58 & 31 & 0.001 & 0.7 \\
\hline HW & Sep & $T_{\mathrm{s} 10}=0.51 T_{\mathrm{a}}+7.3$ & 0.91 & 26 & 0.001 & 0.9 \\
\hline $\mathrm{HW}^{\mathrm{a}}$ & Oct & $T_{\mathrm{s} 10}=0.39 T_{\mathrm{a}}+3.5$ & 0.49 & 49 & 0.001 & 1.4 \\
\hline $\mathrm{RP}$ & May & $T_{\mathrm{s} 10}=0.42 T_{\mathrm{a}}+3.0$ & 0.80 & 27 & 0.001 & 1.3 \\
\hline $\mathrm{RP}$ & Jun & $T_{\mathrm{s} 10}=0.46 T_{\mathrm{a}}+6.0$ & 0.75 & 30 & 0.001 & 1.4 \\
\hline $\mathrm{RP}$ & Jul & $T_{\mathrm{s} 10}=0.28 T_{\mathrm{a}}+12.5$ & 0.55 & 31 & 0.001 & 0.8 \\
\hline $\mathrm{RP}$ & Aug & $T_{\mathrm{s} 10}=0.31 T_{\mathrm{a}}+11.6$ & 0.54 & 31 & 0.001 & 0.6 \\
\hline $\mathrm{RP}$ & Sep & $T_{\mathrm{s} 10}=0.53 T_{\mathrm{a}}+7.1$ & 0.83 & 30 & 0.001 & 1.5 \\
\hline $\mathrm{RP}$ & Oct & $T_{\mathrm{s} 10}=0.34 T_{\mathrm{a}}+3.2$ & 0.52 & 21 & 0.001 & 0.8 \\
\hline YG & May & $T_{\mathrm{s} 10}=0.52 T_{\mathrm{a}}+5.6$ & 0.75 & 26 & 0.001 & 2.0 \\
\hline YG & Jun & $T_{\mathrm{s} 10}=0.42 T_{\mathrm{a}}+10.3$ & 0.83 & 30 & 0.001 & 1.0 \\
\hline YG & Jul & $T_{\mathrm{s} 10}=0.36 T_{\mathrm{a}}+12.9$ & 0.75 & 31 & 0.001 & 0.7 \\
\hline YG & Aug & $T_{\mathrm{s} 10}=0.39 T_{\mathrm{a}}+11.6$ & 0.73 & 31 & 0.001 & 0.6 \\
\hline YG & Sep & $T_{\mathrm{s} 10}=0.60 T_{\mathrm{a}}+6.8$ & 0.85 & 30 & 0.001 & 1.7 \\
\hline YG & Oct & $T_{\mathrm{s} 10}=0.46 T_{\mathrm{a}}+3.8$ & 0.60 & 28 & 0.001 & 1.6 \\
\hline
\end{tabular}

periods: soil warming (May to July) and soil cooling (August to October) for 3 cover types (Table 2). The models developed for HW, RP, and YG were used for HW and MIX forests, RP and JP, YG and NF, respectively.

We also used other independent field $T_{\mathrm{s} 5}$ measurements obtained from 17 sites throughout the growing seasons of 1999 and 2000 in the landscape to verify coarse-resolution $T_{\mathrm{a}}$ data and our methodology in both temporal (grouped by month) and spatial (grouped by sites) dimensions.

\subsection{Estimating SRR across entire landscape}

Although both $T_{\mathrm{s}}$ and soil moisture $\left(M_{\mathrm{s}}\right)$ control $\mathrm{SR}, T_{\mathrm{s}}$ shows a greater impact on SR in non-arid areas (Edwards 1975, Houghton et al. 1983, Parker et al. 1984, Zheng et al. 1993, Lloyd \& Taylor 1994, Davidson et al. 1998, Janssens et al. 2000, Raich et al. 2002, Euskirchen et al. 2003, Jones et
Soil temperatures at 5 and $10 \mathrm{~cm}$ depths $\left(T_{\mathrm{s} 5}\right.$ and $T_{\mathrm{s} 10 \text {, }}$ respectively) were simultaneously measured using HOBO H8 (Onset Computer) data logger at $14 \mathrm{HW}$, $\mathrm{RP}$, and YG forests. We recorded half-hourly $T_{\mathrm{s}}$ from 3 TMC6-HA or TMC6-HB temperature sensors. Each data logger had 2 sensors installed at 5 and $10 \mathrm{~cm}$ depths of soils. Measurements were recorded from 20 May to 31 October 2003. $T_{\mathrm{s} 5}$ and $T_{\mathrm{s} 10}$ were smoothed with a $3 \mathrm{~d}$ moving average for establishing regression models for 3 generalized cover types during soil warming (May to July) and cooling (August to October) periods, respectively (Table 2 ).

We conducted a 2-step procedure to predict $T_{\mathrm{s} 5}$, the driving variable used in our SRR models (Euskirchen et al. 2003), from $T_{\mathrm{a}}$. This procedure was necessary because there were no simultaneous measurements of $T_{\mathrm{a}}$ and $T_{\mathrm{s} 5}$ available to establish direct relationships between the 2 variables. First, monthly mean $T_{\mathrm{a}}$ were converted to monthly mean $T_{\mathrm{s} 10}$ based on regression equations developed from field measurements for major cover types (e.g. HW, RP, and YG forest/ shrub, Table 1) in 2002. Second, we adjusted monthly mean $T_{\mathrm{s} 10}$ to $T_{\mathrm{s} 5}$ based on field measurements in 2003. The relationships were grouped to 2 al. 2003). To estimate LMSRR, we used SRR- $T_{\mathrm{s}}$ empirical models for the major cover types (Table 3) developed from a previous study in this landscape (Euskirchen et al. 2003). SRR were taken through 2 sampling seasons (June to September 1999, and April to October 2000) using a cylindrical chamber of known volume connected to an infrared gas analyzer (PP Systems). Ten collars, constructed from PVC pipe, were installed in the spring prior to taking measurements at each site. The collars created a tight seal between the SR chamber and forest soil. Measurements were made at 3 replicate sites for each of the 6 dominant cover types within the study area (Euskirchen et al. 2003). The instrument was calibrated weekly, as specified by
Table 2. Regression equations used for converting soil temperatures at $10 \mathrm{~cm}$ depth $\left(T_{\mathrm{s} 10},{ }^{\circ} \mathrm{C}\right)$ to soil temperatures at $5 \mathrm{~cm}$ depth $\left(T_{\mathrm{s} 5},{ }^{\circ} \mathrm{C}\right)$ based on field observations (Chequamegon National Forest) for the soil warming period (May to July) and soil cooling period (August to October) for 3 cover types: HW, hard-wood; RP, red pine; YG, young growth

\begin{tabular}{|lllcrc|}
\hline Cover type & Month & Equation & $\mathrm{r}^{2}$ & $\mathrm{~N}$ & $\mathrm{p}$ \\
\hline $\mathrm{HW}$ & May-Jul & $T_{\mathrm{s} 5}=1.08 T_{\mathrm{s} 10}-0.7$ & 0.95 & 68 & 0.001 \\
$\mathrm{HW}$ & Aug-Oct & $T_{\mathrm{s} 5}=1.37 T_{\mathrm{s} 10}-4.0$ & 0.93 & 92 & 0.001 \\
RP & May-Jul & $T_{\mathrm{s} 5}=1.03 T_{\mathrm{s} 10}+2.4$ & 0.80 & 71 & 0.001 \\
RP & Aug-Oct & $T_{\mathrm{s} 5}=1.22 T_{\mathrm{s} 10}-2.0$ & 0.96 & 91 & 0.001 \\
YG & May-Jul & $T_{\mathrm{s} 5}=1.05 T_{\mathrm{s} 10}+3.0$ & 0.96 & 68 & 0.001 \\
YG & Aug-Oct & $T_{\mathrm{s} 5}=1.20 T_{\mathrm{s} 10}-1.5$ & 0.96 & 92 & 0.001 \\
& & & & & \\
\hline
\end{tabular}


Table 3. Soil respiration rates (SRR, $\left.\mathrm{g} \mathrm{CO}_{2} \mathrm{~m}^{-2} \mathrm{~h}^{-1}\right)$ for major cover types in the study area (HW: hardwood; NF: non-forested; YG: young growth; JP: jack pine; and RP: red pine). $T_{\mathrm{s} 5}$ : soil temperature at $5 \mathrm{~cm}$ depth $\left({ }^{\circ} \mathrm{C}\right)$ (Euskirchen et al. 2003)

\begin{tabular}{|c|c|c|}
\hline Cover type & Equation & $\mathrm{r}^{2}$ \\
\hline HW & $\mathrm{SRR}=0.2974 \times \mathrm{e}^{0.0635 T_{\mathrm{s} 5}}$ & 0.73 \\
\hline NF & $\mathrm{SRR}=0.2594 \times \mathrm{e}^{0.0513 T_{\mathrm{s} 5}}$ & 0.67 \\
\hline YG & $\mathrm{SRR}=0.3195 \times \mathrm{e}^{0.0715 T_{\mathrm{s} 5}}$ & 0.65 \\
\hline JP & $\mathrm{SRR}=0.3235 \times \mathrm{e}^{0.0514 T_{\mathrm{S} 5}}$ & 0.45 \\
\hline $\mathrm{RP}$ & $\mathrm{SRR}=0.3059 \times \mathrm{e}^{0.0611 T_{\mathrm{S} 5}}$ & 0.55 \\
\hline
\end{tabular}

the manufacturer (PP Systems), to ensure that the measurements stayed within the accuracy rating of $\pm 1 \%$. At the time of each SR measurement, $T_{\mathrm{s} 5}$ was measured adjacent to each PVC collar using a digital thermometer (Hanna Instruments). Continuous $T_{\mathrm{s}}$ profiles of each site were recorded at hourly to half-hourly intervals using HOBO 4-Channel External data loggers (Onset).

We did not use models that include an $M_{\mathrm{s}}$ term for the primary reason that there was no reliable methodology to convert monthly total precipitation to monthly mean $M_{\mathrm{s}}$ for model applications across the entire landscape. This is due to the fact that the intensity and frequency of precipitation, soil properties, and rates of evapotranspiration all affect the relationship between precipitation and $M_{\mathrm{s}}$. In addition, $T_{\mathrm{s}}$ and soil water content tend to be negatively correlated throughout the growing season (Davidson et al. 1998) and $T_{\mathrm{S}}$ has had the most explanatory power in the study area, explaining 45 to $73 \%$ of the variability in SRR (Euskirchen et al. 2003). The inclusion of an $M_{\mathrm{s}}$ term and a $T_{\mathrm{s}} \times M_{\mathrm{s}}$ interaction term into our SR model increased the $\mathrm{r}^{2}$ values only by 0.04 to 0.12 for 3 cover types (Euskirchen et al. 2003). These 3 types combined accounted for 21 to $31 \%$ of the total area during the $30 \mathrm{yr}$ study period. To calculate SRR for mixed forests, we used both hardwood and softwood equations weighted by their field observed proportions $\left(\mathrm{SRR}_{\mathrm{MIX}}=\mathrm{SRR}_{\mathrm{HW}} \times 0.6+\mathrm{SRR}_{\mathrm{JP}} \times 0.2+\mathrm{SRR}_{\mathrm{RP}} \times 0.2\right)$.

\subsection{Effects of temperature and land cover on SRR}

We maximized the detectable influence of temperature and land cover by selecting 2 extremes of each variable among the 6 years. We chose the 2 land-cover maps for the years of 1972 and 2001 since it was in these years that the decrease in forestlands and increase in NF and YG forest areas were the greatest. We also chose the climatic data sets for 1987 and 1992 since these showed the greatest difference in growing

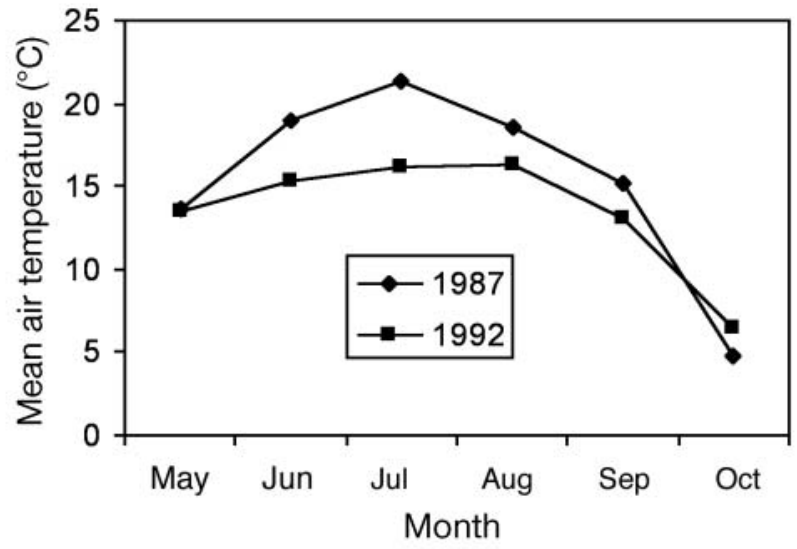

Fig. 2. Monthly mean air temperatures in the Chequamegon National Forest between 1987 and 1992

season mean temperatures $\left(15.4\right.$ and $13.4^{\circ} \mathrm{C}$, respectively, Fig. 2) among the 6 years. We simulated the LMSRR at a monthly step using 4 different combinations: (1) 1972 land-cover map and 1992 temperature data, as base run for comparisons with other combinations; (2) 1972 land-cover map and 1987 temperature data; (3) 2001 land-cover map and 1992 temperature data; and (4) 2001 land-cover map and 1987 temperature data. Growing season LMSRR were then calculated. We further completed the analyses of growing season LMSRR among the 4 testing scenarios by comparing (1) and (2) to determine the sole effects of temperature, comparing (1) and (3) to illustrate the sole effects of land-use change, and comparing (1) and (4) to examine the effects of the changes in temperature and land use combined.

To compare seasonal variations between LMSRR and $T_{\mathrm{a}}$ from May to October among the 6 simulated years, we calculated the coefficient of variation $(\mathrm{CV}$, $\%)$ for both variables in each given month because the units for the 2 variables were not in the same magnitude. To examine the inter-annual relationship between LMSRR and $T_{\mathrm{a}}$ among the 6 years, we calculated the relative changes for both variables by dividing the values in each given year by their 6 yr means.

\section{RESULTS}

Changes in LMSRR during the growing season basically followed a unimodal pattern that reached the highest value in July (1.03 to $1.15 \mathrm{~g} \mathrm{CO}_{2} \mathrm{~m}^{-2} \mathrm{~h}^{-1}$ ) and averaged $1.10 \mathrm{~g} \mathrm{CO}_{2} \mathrm{~m}^{-2} \mathrm{~h}^{-1}$ among the 6 years and decreased slightly in August (Fig. 3a). The lowest LMSRR occurred in October and was on average $63 \%$ less than that of July. The values varied from 0.38 to $0.44 \mathrm{~g} \mathrm{CO}_{2} \mathrm{~m}^{-2} \mathrm{~h}^{-1}$, with an average of $0.41 \mathrm{~g} \mathrm{CO}_{2} \mathrm{~m}^{-2}$ $\mathrm{h}^{-1}$ (Fig. 3a). September had the greatest inter-annual 

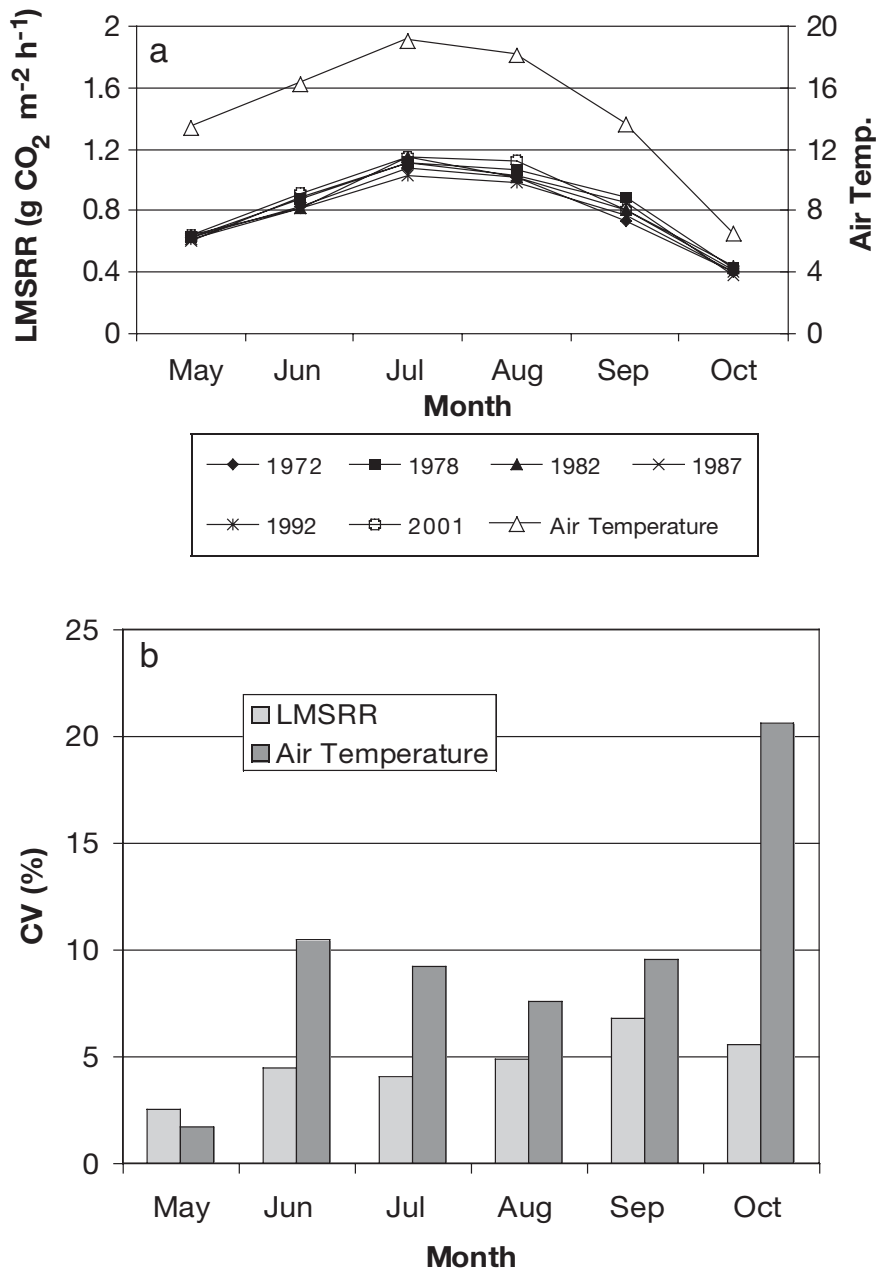

Fig. 3. (a) Seasonal changes in landscape mean soil respiration rates (LMSRR) from May to October among the 6 simulated years and the mean monthly air temperature $\left({ }^{\circ} \mathrm{C}\right)$ of the 6 years, and (b) comparison of coefficients of variation (CV, $\%)$ between LMSRR and air temperature, from May to October among the 6 simulated years in Chequamegon National Forest

variation in LMSRR and May had the smallest, with standard deviations (SD) of 0.055 and $0.016 \mathrm{~g} \mathrm{CO}_{2} \mathrm{~m}^{-2}$ $\mathrm{h}^{-1}$, respectively. Comparison of CVs between LMSRR and $T_{\mathrm{a}}$ from May to October demonstrated that: (1) LMSRR showed smaller variation than that of $T_{\mathrm{a}}$ in all months except in May; (2) variations of LMSRR in soil cooling months (August to October) varied more than in the warming months (May to July) while $T_{\mathrm{a}}$ varied less in the cooling months than in the temporally symmetric warming months (e.g. August vs. July and September vs. June).

Temporal dynamics of monthly LMSRR before and after their peak value in July differed (Fig. 3a). The LMSRR increased linearly to a peak and then seemed to decrease at an accelerating rate. LMSRR values in
May, June, August, September, and October averaged about $57,78,94,73$, and $37 \%$ of their July's SRR, respectively. LMSRR decreased by $49 \%$ from September to October. While the CV value $(7.5 \%)$ of LMSRR in September was much higher than that in June $(3.9 \%)$, the $\mathrm{CV}$ value of mean landscape $T_{\mathrm{a}}$ was lower than that in June (Fig. 3b). A similar pattern was also observed in precipitation, the CV value $(27 \%)$ being smaller in September was smaller than that in June (30\%) among the 6 years (data not shown).

Changes in inter-annual growing season LMSRR followed the similar trend of inter-annual growing season mean $T_{\mathrm{a}}$ variations except in 1982 (Fig. 4a). The inconsistent pattern in 1982 and a mismatched magnitude of change in 1987 clearly indicated that other factors such as land-use pattern and distribution of temperature within the growing season would also affect LMSRR variation. Of the cover types, changes in the area of YG
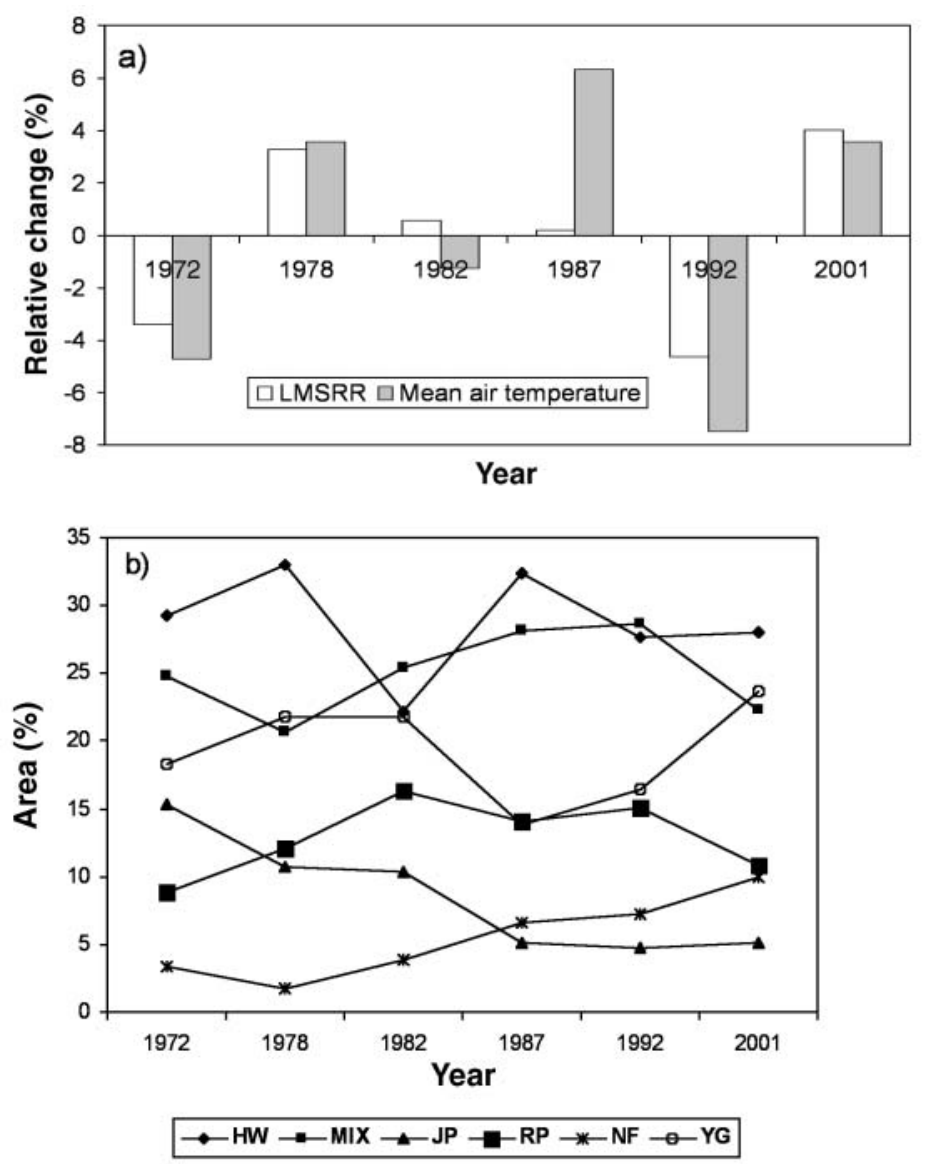

Fig. 4. (a) Comparison of temporal variation (1972-2001) between growing season landscape mean soil respiration rates (LMSRR, $\mathrm{g} \mathrm{CO}_{2} \mathrm{~m}^{-2} \mathrm{~h}^{-1}$ ) and mean air temperatures $\left({ }^{\circ} \mathrm{C}\right.$ ) calculated as relative changes to their means of the 6 years, and (b) changes in cover type composition among the 6 years. HW: hardwood; MIX: mixed hardwood/conifer; JP: jack pine; RP: red pine; NF: non-forested; YG: young growth 

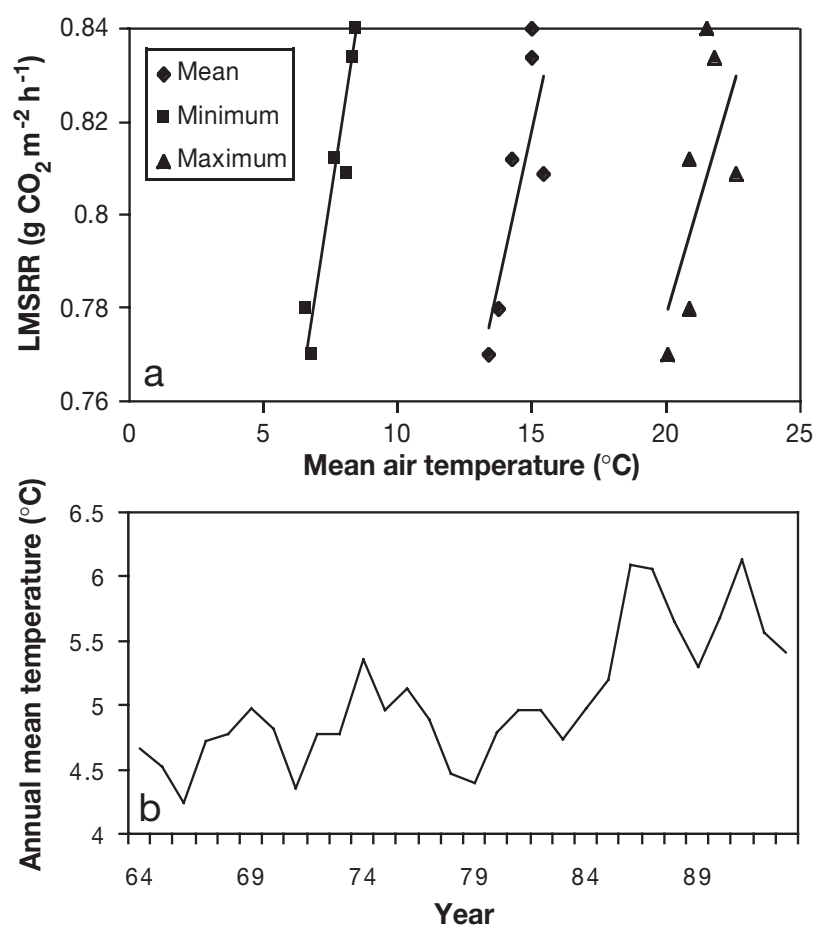

Fig. 5. (a) Relationships between landscape mean soil respiration rates (LMSRR) and landscape minimum air temperature $\left(\mathrm{LMSRR}=0.034 \times T_{\min }+0.43, \mathrm{r}^{2}=0.91\right)$, maximum air temperature $\left(\operatorname{LMSRR}=0.020 \times T_{\max }+0.38, \mathrm{r}^{2}=0.39\right)$, and mean air temperatures $\left({ }^{\circ} \mathrm{C}\right)\left(\mathrm{LMSRR}=0.030 \times T_{\text {mean }}+0.38, \mathrm{r}^{2}=0.68\right)$ from May to October. Each point represents growing season LMSRR and air temperatures for 1 of the 6 years $(1972-2001)$. (b) A warming trend in the study area based on the observations from 1964 to 1993 (after 3 yr running average) at the Farm Experimental Station, Ashland, WI (data after 1994 were missing)

influenced the inter-annual growing season LMSRR variation the most (data not shown).

Variation of growing season LMSRR among the 6 years correlated well with temperature fluctuation. $T_{\min }$ had a stronger relationship with LMSRR than mean or $T_{\max }$ (slope $=0.034, \mathrm{r}^{2}=0.91$, Fig. 5a).

Monthly regressions for estimating $T_{\mathrm{s} 10}$ from $T_{\mathrm{a}}$ generally showed clear relationships across all 3 major cover types in the study area, with an average $\mathrm{r}^{2}$ value of 0.68 , ranging from 0.25 to 0.91 . The results indicated that the standard errors (SE) of regressions were usually higher in early spring and the fall than those in summer months. The values of SE were also related to cover types with higher mean SE and variation among the months for $\mathrm{YG}$ (ranging from 0.6 to $2.0^{\circ} \mathrm{C}$ with mean $=1.3^{\circ} \mathrm{C}$ ) than those for mature $\mathrm{HW}$ and $\mathrm{RP}$ forests (ranging from 0.7 to $1.4^{\circ} \mathrm{C}$ with mean $=1.1^{\circ} \mathrm{C}$, and from 0.6 to $1.5^{\circ} \mathrm{C}$ with mean $=1.1^{\circ} \mathrm{C}$, respectively; Table 1).

Validation between the measured and estimated $T_{\mathrm{s} 5}$ using regression models (Table 2) suggested that the monthly $T_{\mathrm{a}}$ data from the NOAA web site and our presented methodology to convert $T_{\mathrm{a}}$ to $T_{\mathrm{s}}$ are valid for landscape-scale analyses. Our field measurements were widely distributed across the landscape (Fig. 6a). While the estimated $T_{\mathrm{s}}$ matched well temporally $\left(\mathrm{R}^{2}=\right.$ $0.95, N=6, p=0.001$, Fig. $6 b$ ), they did not do so spatially $\left(R^{2}=0.25, N=17, p=0.05\right.$, Fig. $\left.6 c\right)$.

Our results indicated that increasing the growing season mean $T_{\mathrm{a}}$ by $2^{\circ} \mathrm{C}$ in the Chequamegon National Forest could raise LMSRR by $6.7 \%$ based on the landscape mosaic in 1972 and $7 \%$ on the landscape mosaic in 2001 (Fig. 7). When $T_{\mathrm{a}}$ were kept constant, changes in land-cover composition from 1972 to 2001 increased

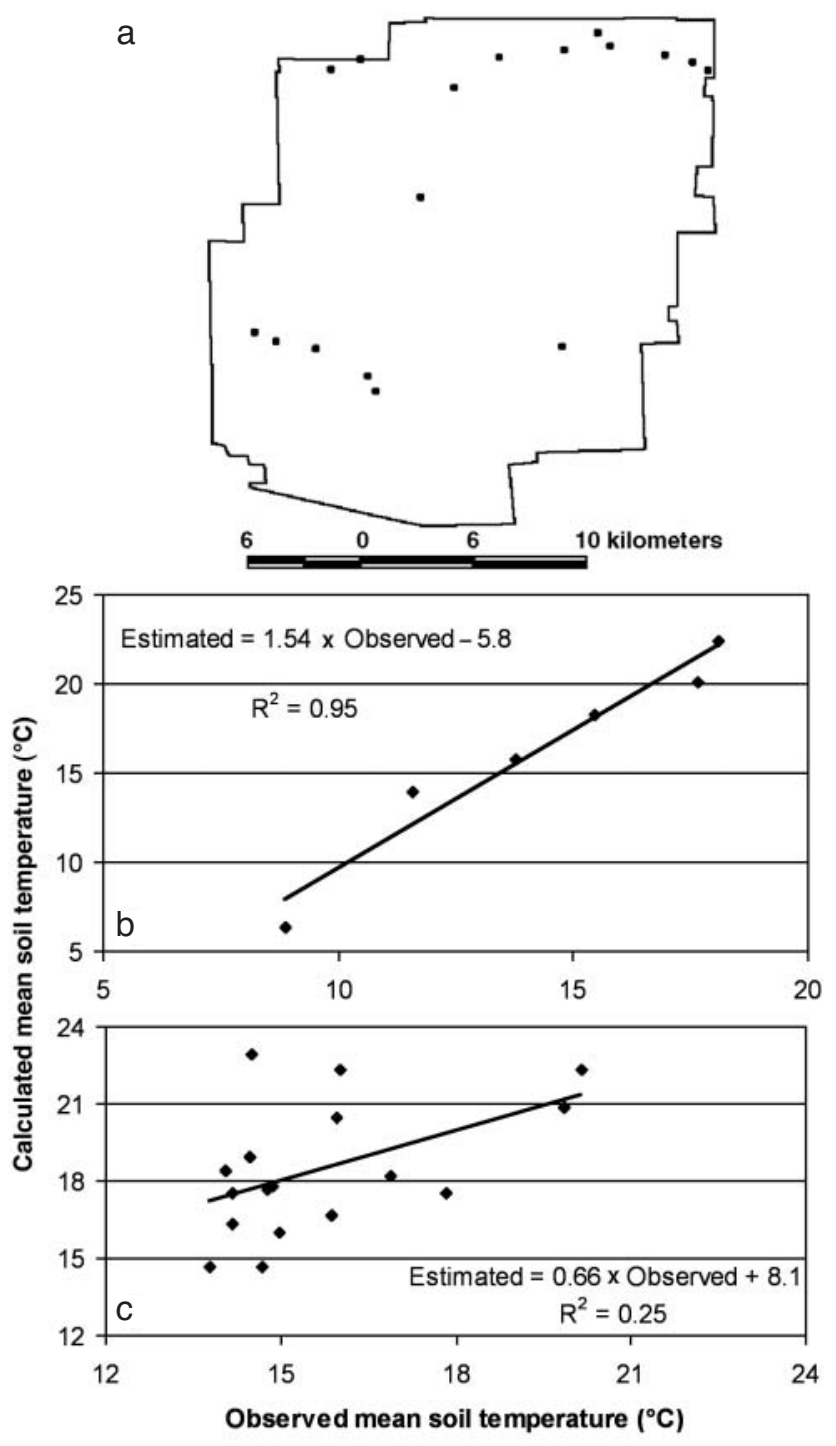

Fig. 6. (a) Spatial distribution of the 17 plots in the Chequamegon National Forest whose soil temperatures at $5 \mathrm{~cm}$ depth were measured in the field and calculated from the regressions during May to October. Mean soil temperatures obtained (b) by months $(\mathrm{N}=6)$ to validate the temporal match and (c) by plots $(\mathrm{N}=17)$ to validate the spatial match 


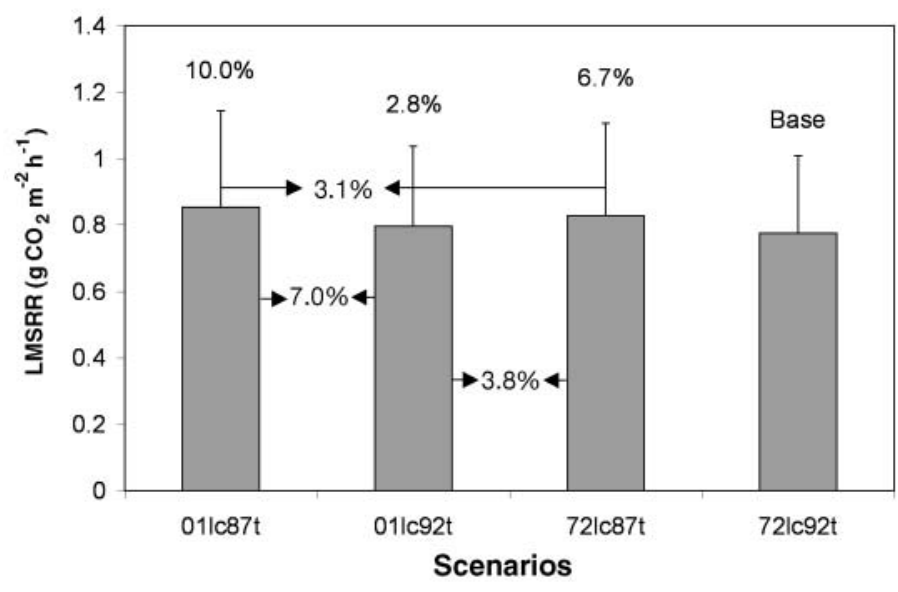

Fig. 7. Changes in landscape mean soil respiration rates (LMSRR) in the Chequamegon National Forest between 1972 and 2001 caused by climate change and land use change were quantified under 4 scenarios, from right to left: (1) 1972 land cover map (72lc) and 1992 growing season monthly air temperature data $(92 t$, the coldest growing season among the 6 years) used as base value; (2) 72lc and 1987 growing season monthly air temperature data $(87 \mathrm{t}$, the hottest growing season among the 6 years); (3) 2001 land cover map (01lc) and 92t; and (4) 01lc and 87t. SRR calculated from the Scenario 1 was used as base value for comparison with other simulated SRR values. Bar represents $+1 \mathrm{SD}$ and values in $\%$ at the top show the relative changes in SRR compared to the base value. Values between the arrow signs are relative changes (always using the larger number as numerator) between the 2 indicated scenarios

LMSRR by $2.8 \%$ in a cooler year (1992) and $3.1 \%$ in a warmer year (1987). The combined effects of changes in $T_{\mathrm{a}}$ and land-cover composition on SRR were more complicated, varying from 3.8 to $10.0 \%$, depending on how land cover interacted with climate. These changes in LMSRR were not statistically significant because of larger unexplained variances in the SRR- $T_{\mathrm{S}}$ models (27 to $55 \%$, Euskirchen et al. 2003) we used for the simulations. However, the detected changes in LMSRR caused by changes in climate and land use could have ecological significance and should not be ignored. Having no statistical significance does not necessarily mean there is no biological or ecological significance (Scientific Committee on Plants 2002, Schratzberger et al. 2002).

\section{DISCUSSION}

We examined the effects of changes in temperature and land use on LMSRR over a $30 \mathrm{yr}$ period in a managed forest landscape. Our estimated values compared well with reported values in a temperate mixed hardwood forest at similar latitudes (Davidson et al. 1998). The range of variation in each of the driving variables (land use and temperature) was close to magnitudes previously reported. For example, from 1972 to 2001, the intermediate and mature forest cover types declined about $12 \%$ while the non-forested and young growth cover types increased from 22 to $34 \%$ in the Chequamegon National Forest. The annual mean loss rate of forest cover $(0.4 \%)$ in the Chequamegon National Forest was similar to that reported in the Appalachian highlands, North Carolina, and the Olympic peninsula, Washington, USA, where the annual mean loss rate of forest cover on public land was about $0.3 \%$ during a 16 yr period from 1975 to 1991 (Turner et al. 1996). Differences in monthly mean $T_{\mathrm{a}}$ from June to September between 1987 and 1992 used in this study ranged from 2 to $5^{\circ} \mathrm{C}$ (Fig. 2), corresponding well with the 2 to $6^{\circ} \mathrm{C}$ projected increases in summer averages in northern latitudes (www. climatechangeconnection.org/pages/forests.html). Schimel et al. (2000) suggested that the changes in land-use patterns in recent decades in the US might have effects on the carbon dynamics of ecosystems as large as those caused by climate because of regrowth on abandoned agricultural land. However, our study showed that the effects from land-use change were smaller than the effects from climate. A partial explanation for this is that our study area is located in a National Forest, where agricultural activities are very limited.

The LMSRR values of June and September among the 6 years were of similar magnitude (Fig. 3); however, a Student's $t$-test indicated that mean $T_{\mathrm{a}}$ in June $\left(16.3^{\circ} \mathrm{C}\right)$ was significantly higher than that in September $\left(13.7^{\circ} \mathrm{C}, \mathrm{p}=0.02\right)$. While the CV $(7.5 \%)$ of LMSRR in September among the 6 years was $92 \%$ higher than that in June $(3.9 \%)$, both $\mathrm{CV}$ values for $T_{\mathrm{a}}$ and total precipitation (9.5 and $27 \%$, respectively) in September were lower than those in June (10.5 and 30\%). Such disagreement strongly suggested that litter layer depths associated with cover types across the landscape could be an important factor determining spatial variation of $T_{\mathrm{s}}$ in its cooling process, thus contributing to the larger variation in LMSRR. Rapid decrease in LMSRR from September to October could be also attributed to a dramatic shutdown of photosynthesis processes (Hogberg et al. 2001) and the decrease in day length.

Inter-annual variation of LMSRR did not always vary accordingly with that of mean $T_{\mathrm{a}}$, indicating that other factors such as land-cover composition and temporal pattern of temperature distribution across the growing season may also determine the general direction and degree of changes in LMSRR compared to those changes in $T_{\mathrm{a}}$. For example, the growing season mean $T_{\mathrm{a}}$ in 1982 was $1.2 \%$ below the average $T_{\mathrm{a}}$ of the 6 years, while the LMSRR increased $(0.6 \%$, Fig. 4a) 
because the $T_{\mathrm{a}}$ in July was $0.9^{\circ} \mathrm{C}$ higher than the $6 \mathrm{yr}$ average. Growing season mean $T_{\mathrm{a}}$ increased substantially in 1987 (6.4\%), compared to that of the mean value, while SRR increased slightly $(0.2 \%)$. The minor increase in SRR can be attributed to a $37 \%$ reduction (from1982) in the area of young forests, which have the highest SRR among all land-cover types (Fig. 3).

LMSRR in the study area tends to be more sensitive to increases of minimum $T_{\mathrm{s}}$ than to that of maximum temperatures (Fig. 5a). Our findings agreed with other reported results that the temperature sensitivity of soil $\mathrm{CO}_{2}$ efflux decreases with increasing $T_{\mathrm{s}}$ (Howard \& Howard 1993, Lloyd \& Taylor 1994). For example, in the absence of moisture limitations, an increase from 0 to $1^{\circ} \mathrm{C}$ would result in a $22 \%$ increase in respiration, while an increase from 25 to $26^{\circ} \mathrm{C}$ leads to a $5 \%$ increase (Lloyd \& Taylor 1994). These findings could have significant impacts on carbon cycling in northern temperate ecosystems. While the Intergovernmental Panel on Climate Change stated that the observed increase in global mean temperature over the last century was 0.3 to $0.6^{\circ} \mathrm{C}$ (Watson et al. 1995), a similar warming trend was apparent in our study area with a $1.9^{\circ} \mathrm{C}$ increase in annual mean $T_{\mathrm{a}}$ during a $30 \mathrm{yr}$ period (Fig. 5b). The effect of increased temperatures on net carbon exchange will vary depending on timing. If the warming mainly occurs in winter months, then it may have little impact on SR or photosynthetic processes. In fall or spring months, it may enhance SR efflux more than photosynthesis, and in summer months, the influence may enhance photosynthesis more than SR. Consequently, it may enhance the source strength of these forests in fall or spring and increase the sink strength in summer.

Field measurements of $T_{\mathrm{s} 5}$ suggested that the monthly mean $T_{\mathrm{a}}$ data from NOAA and our methodology to convert the $T_{\mathrm{a}}$ to $T_{\mathrm{s}}$ are valid for LMSRR studies. Spatial correlation between the observed and estimated $T_{\mathrm{s}}$ showed a lower level of significance $(\mathrm{p}=0.05$, $\left.\mathrm{R}^{2}=0.25\right)$ compared to the level of significance for temporal correlation $\left(p=0.001, R^{2}=0.95\right.$; Fig. $\left.6 b, c\right)$, but, nevertheless, this did indicate that the estimated $T$ corresponded to actual spatial variation to some degree. It should be noted that less significant correlation between the observed and estimated $T_{\mathrm{s}}$ on spatial than on temporal dimension is expected because of a mismatch in spatial resolutions. While the estimated $T_{\mathrm{s}}$ were based on air temperature data at $4 \mathrm{~km}$ pixel resolution, observed $T_{\mathrm{s}}$ were collected at much finer spatial resolution $(10 \mathrm{~m})$ at which many local factors such as soil physical properties, soil water content, and slope and aspect of the terrain can affect the measurements.

This study demonstrated that the combined effects of changes in $T_{\mathrm{a}}$ and land-cover composition on SRR were more complicated than the effects from a single variable: larger variation resulted from combined effects (Fig. 7). The variation can be caused by the direction of change in land-cover types when each type exhibits different SRR. The observed variation can also be affected by how land-cover change and climate change interacted. For example, if a landscape potentially experiences high SRR through the creation of young forest but undergoes a cooler-than-average year, then the effects on SRR are contradictory, and the 2 factors may moderate one another. If the landscape dominated by younger forests interacts with a warmerthan-average year, then the effects on SRR complement each other and enhance landscape SRR. We have demonstrated that the cumulative effect, however, does not necessarily equal the sum of the effects from the 2 individual factors (e.g. $10 \%>6.7 \%+2.8 \%$, Fig. 7).

There were several possible error sources associated with our LMSRR estimates. (1) There are inconsistencies in the temporal scales on which the SRR and temperature regressions were built, or on which the $T_{\mathrm{a}}$ and cover type composition acted, because of lack of historical data. (2) Our estimated LMSRR might be higher than actual values because the SRR- $T_{\mathrm{s}}$ models were developed using field data collected between 07:00 and 19:00 h. A lack of nighttime SRR, however, should have minimal effect on our analyses since the study was focused on relative changes of LMSRR during the growing season among the years. (3) Our SRR models could have been better if they had included an $M_{\mathrm{s}}$ component (Kang et al. 2004); however, the lack of adequate data necessitates the use of less than ideal models. While inter-annual variability in SR has been previously correlated with inter-annual differences in precipitation for dry biomes such as savannas, bushlands, and deserts (Raich et al. 2002), it may not be as critical in our relatively moist study area. (4) When working from land-cover maps, their accuracy must be considered during interpretation of results. We used a model for young forests (Table 3) to estimate SRR for the RFS cover type because it was the closest one by definition. The disparate composition of vegetation included in this cover type may induce differences in their SRR. Similarly, the composition of the cover type may have changed with management intent across the interval of our study. (5) Mean standard errors (MSE) for monthly regressions used for converting $T_{\mathrm{a}}$ to $T_{\mathrm{s} 10}$ showed higher MSE $\left(1.3^{\circ} \mathrm{C}\right.$ during the growing season) for young growth than those for hardwoods and pine forests (both with averages of $1.1^{\circ} \mathrm{C}$, Table 1). The combined MSE for indirect conversion of $T_{\mathrm{a}}$ to $T_{\mathrm{s} 5}$ was $1.97^{\circ} \mathrm{C}$. Despite these weaknesses, this study elucidated the interaction between changes in temperature and land-cover composition on landscape SRR across 
an entire landscape, provided useful characterization of seasonal changes in LMSRR among the years, and established a framework for future regional soil carbon efflux studies related to changes in climate and land use. The methodology demonstrated in this study can be applied in landscapes experiencing analogous climate, although for more arid regions the development of a soil moisture component is critical. Consequently, it would be interesting to compare the results from this study to similar studies conducted in other landscapes with similar variations in climate regimes and various degrees of land use disturbances and land-use history. Better understanding of LMSRR associated with the changes in climate and land use will improve our ability to quantify ecosystems' carbon budgets.

Acknowledgements. The Joint Fire Science Program primarily supported this study. The National Science Foundation (DEB-0129405) and the Northern American Global Climate Change of USDA Forest Service provided partial support. Anonymous reviewers provided valuable criticism of an earlier version of the paper.

\section{LITERATURE CITED}

Albert DA (1995) Regional landscape ecosystems of Michigan, Minnesota, and Wisconsin: a working map and classification. Report No. NC-178, USDA Forest Service North Central Forest Experiment Station, St. Paul, MN

Alcamo J, Kreileman GJJ, Bollen JC, van den Born GJ, Gerlagh R, Krol MS, Toet AMC, de Vries HJM (1996) Baseline scenarios of global environmental change. Global Environ Change 6:261-303

Berg B, Staaf H, Wessen B (1987) Decomposition and nutrient release in needle litter from nitrogen-fertilized Scots pine (Pinus sylvestris) stands. Scand J For Res 2:399-415

Bresee MK, Le Moine JM, Mather S, Brosofske KD, Chen J, Crow TR, Rademacher J (2004) Disturbance and landscape dynamics in the Chequamegon National Forest, Wisconsin, USA, from 1972 to 2001. Landsc Ecol 19: 291-309

Brosofske KD, Chen J, Crow TR (2001) Understory vegetation and site factors: implications for a managed Wisconsin landscape. For Ecol Manag 146:75-87

Brown SE, Pregitzer KS, Reed DD, Burton AJ (2000) Predicting daily mean soil temperature from daily mean air temperature in 4 northern hardwood forest stands. For Sci 46: 297-301

Carreiro MM, Sinsabaugh RL, Repert DA, Parkhurst DF (2000) Microbial enzymc shifts explain litter decay responses to simulated nitrogen deposition. Ecology 81: $2359-2365$

Chen J, Saunders SD, Crow T, Brosofske KD, Mroz G, Naiman R, Brookshire B, Franklin J (1999) Microclimatic in forest ecosystems and landscapes. BioScience 49: 288-297

Ciais P, Tans PP, Trolier M, White JWC, Francey RJ (1995) A large northern hemisphere terrestrial $\mathrm{CO}_{2}$ sink indicated by the ${ }^{13} \mathrm{C} /{ }^{12} \mathrm{C}$ ratio of atmospheric $\mathrm{CO}_{2}$. Science 269: 1098-1102

Dai A, Fung IY (1993) Can climate variability contribute to the 'missing' $\mathrm{CO}_{2}$ sink? Global Biogeochem Cycles 7:599-609
Davidson EA, Belk E, Boone RD (1998) Soil water content and temperature as independent or confounded factors controlling soil respiration in a temperate mixed hardwood forest. Global Change Biol 4:217-227

Dixon RK, Brown S, Houghton RA, Solomon AM, Trexler MC, Wisniewski J (1994) Carbon pools and flux of global forest ecosystems. Science 63:185-190

Edwards NT (1975) Effects of temperature and moisture on carbon dioxide evolution in a mixed deciduous forest floor. Soil Sci Soc Am Proc 39:361-365

ERDAS (1999) ERDAS IMAGINE 8.4: Tour guides, Vol 8.4. ERDAS, Atlanta, GA

Euskirchen ES, Chen J, Bi R (2001) Effects of edges on plant communities in a managed landscape in northern Wisconsin. For Ecol Manag 148:93-108

Euskirchen ES, Chen J, Li H, Gustafson EJ, Crow TR (2002) Modeling net carbon flows under alternative management regimes at a landscape level. Ecol Model 154:75-91

Euskirchen ES, Chen J, Gustafson EJ, Ma S (2003) Soil respiration at dominant patch types within a managed northern Wisconsin landscape. Ecosystems 6:595-607

Fan S, Gloor M, Mahlman J, Pacala SW, Sarmiento J, Takahashi T, Tans P (1998) A large terrestrial carbon sink in North America implied by atmospheric and oceanic dioxide data and models. Science 282(5388):442-446

Field CB, Chapin FS III, Matson PA, Mooney HA (1992) Responses of terrestrial ecosystems to the changing atmosphere: a resource-based approach. Annu Rev Ecol Syst 23:201-235

Giardina CP, Ryan MG (2002) Total belowground carbon allocation in a fast-growing Eucalyptus plantation estimated using a carbon balance approach. Ecosystems 5:487-499

Goulden ML, Munger JW, Fan SM, Daube BC, Wofsy SC (1998) Sensitivity of boreal forest carbon balance to soil thaw. Science 279:214-217

Grace J, Lloyd J, McIntyre J, Miranda AC and 6 others (1995) Carbon dioxide uptake by an undisturbed tropical rain forest in southwest Amazonia, 1992 to 1993. Science 270: 778-780

Gustafson EJ, Crow TR (1996) Simulating the effects of alternative forest management strategies on landscape structure. J Environ Manag 46:77-94

Hogberg P, Nordgren A, Buchmann N, Taylor AFS and 5 others (2001) Large-scale forest girdling shows that current photothesis drives soil respiration. Nature 411:789-792

Houghton RA, Hobbie JE, Melillo JM, Moore B, Peterson BJ, Shaver GR, Woodwell GM (1983) Changes in the carbon content of terrestrial biota and soils between 1860 and 1980: a net release of $\mathrm{CO}_{2}$ to the atmosphere. Ecol Monogr 53:235-262

Howard DM, Howard PJA (1993) Relationships between $\mathrm{CO}_{2}$ evolution, moisture content and temperature for a range of soil types. Soil Biol Biochem 25:1537-1546

Jackson RB, Canadell J, Ehleringer JR, Mooney HA, Sala OE, Schulze ED (1996) A global analysis of root distributions for terrestrial biomes. Oecologia 108:389-411

Jackson RB, Schenk HJ, Jobbagy EG, Canadell J and 12 others (2000) Belowground consequences of vegetation change and their treatment in models. Ecol Appl 10: 470-483

Janssens IV, Meriresonne L, Ceulemans R (2000) Mean soil $\mathrm{CO}_{2}$ efflux from a mixed forest: temporal and spatial integration. In: Ceulemans RJM, Veroustraete F, Gond V, Van Rensbergen JBHF (eds) Forest ecosystem modeling, upscaling and remote sensing. SPB Academic Publishing, The Hague, p 19-31

Jones CD, Cox P, Huntingford C (2003) Uncertainty in 
climate-carbon-cycle projections associated with the sensitivity of soil respiration to temperature. Tellus 55B: 642-648

Kang S, Lee D, Kimball JS (2004) The effects of spatial aggregation of complex topography on hydrological process simulations within a rugged forest landscape: development and application of a satellite-based topoclimatic model. Can J For Res 34:519-530

Keeling CD, Whorf TP, Wahlen M, Plicht JVd (1995) Interannual extremes in the rate of rise of atmospheric carbon dioxide since 1980. Nature 375:666-670

Keeling CD, Chin JFS, Whorf TP (1996) Increased activity of northern vegetation inferred from atmospheric $\mathrm{CO}_{2}$ measurements. Nature 382:146-149

Lloyd J, Taylor JA (1994) On the temperature dependence of soil respiration. Funct Ecol 8:315-323

Ma S, Chen J, North M, Erickson HE, Bresee MK, Le Moine JM (2004) Short-term effect of experimental burning and thinning on soil respiration in an old-growth, mixedconifer forest. Environ Manag 33(S1):148-159

Magill AH, Aber JD (1998) Long-term effects of experimental nitrogen additions on foliar litter decay and humus formation in forest ecosystems. Plant Soil 203:301-311

Nicholls N, Gruza GV, Jouzel J, Karl TR, Ogallo LA, Parker DE (1996) Observed climate variability and change. In: Houghton JT, Filho LGM, Callander BA, Harris N, Kattenberg A, Maskell K (eds) Climate change 1995. University Press Cambridge, Cambridge

Ogle SM, Breidt FJ, Eve MD, Paustian K (2003) Uncertainty in estimating land use and management impact on soil organic carbon storage for US agricultural lands between 1982 and 1997. Global Change Biol 9:1521-1542

Parker LW, Freckman DW, Steinberger Y, Driggers L, Whitford WG (1984) Effects of simulated rainfall and litter quantities on desert soil biota: soil respiration, microflora, and protozoa. Pedobiologia 27:185-195

Potter CS, Klooster SA (1998) Interannual variability in soil trace gas $\left(\mathrm{CO}_{2}, \mathrm{~N}_{2} \mathrm{O}\right.$, NO) fluxes and analysis of controllers on regional to global scales. Global Biogeochem Cycles 12:621-635

Raich JW, Potter CS (1995) Global patterns of carbon dioxide emission from soils. Global Biogeochem Cycles 9:23-36

Raich JW, Schlesinger WH (1992) The global carbon dioxide flux in soil respiration and its relationship to vegetation and climate. Tellus 44B:81-99

Raich JW, Potter CS, Bhagawati D (2002) Interannual variability in global soil respiration, 1980-94. Global Change Biol 8:800-812

Rayner PJ, Enting IG, Francey RJ, Langenfelds RL (1999) Reconstructing the recent carbon cycle from atmospheric $\mathrm{CO}_{2}, \delta^{13} \mathrm{C}$ and $\mathrm{O}_{2} / \mathrm{N}_{2}$ observations. Tellus $51 \mathrm{~B}: 213-232$

Richards JF (1991) Land transformation. In: Turner BL, Clark

Editorial responsibility: Robert Davis,

Charlottesville, Virginia, USA
WC, Kates RW, Richards JF, Mathews JT, Meyer WB (eds) The earth as transformed by human action: global and regional changes in the biosphere over the past 300 years. Cambridge University Press, Cambridge, p 163-178

Saunders SC, Chen J, Drummer TD, Crow TR (1999) Modeling temperature gradients across edges over time in a managed landscape. For Ecol Manag 117:17-31

Schimel D, Melillo J, Tian HQ, McGuire AD and 11 others (2000) Contribution of increasing $\mathrm{CO}_{2}$ and climate to carbon storage by ecosystems in the United States. Science 287:2004-2006

Schratzberger M, Dinmore TA, Jennings S (2002) Impacts of trawling on the diversity, biomass and structure of meiofauna assemblages. Mar Biol 140:83-93

Scientific Committee on Plants (2002) Opinion of the scientific committee on plants on additional questions from the commission concerning the evaluation of vinclozolin in the context of council directive 91/414/EEC. Report No. SCP/VINCLO-TER/002-Final, European Commission. Available at: http://europa.eu.int/comm/food/fs/sc/scp/ out130_ppp_en.pdf)

Stocks BJ, Fosberg MA, Wotton MB, Lynham TJ, Ryan KC (2000) Climate change and forest fire activity in North American boreal forest. In: Caldwell MM, Heldmaier G, Lange OL, Mooney HA, Schulze ED, Sommer U (eds) Fire, climate change, and carbon cycling in the boreal forest, Vol 138. Springer-Verlag, New York, p 368-375

Tans PP, Fung IY, Takahashi T (1990) Observational constrains on the global atmospheric $\mathrm{CO}_{2}$ budget. Science 247:1431-1438

Thierron V, Laudelot H (1996) Contribution of root respiration to total $\mathrm{CO}_{2}$ efflux from the soil of a deciduous forest. Can J For Res 26:1142-1148

Turner MG, Wear DN, Flamm RO (1996) Land ownership and land cover change in the Southern Appalachian highlands and Olympic peninsula. Ecol Appl 6:1150-1172

Watkins RZ, Chen J, Pickens J, Brosofske KD (2003) Effects of forest roads on understory plants in a managed hardwood landscape. Conserv Biol 17:411-419

Watson RT, Zinyowera MC, Moss RH (1995) Climate change 1995: impacts, adaptations and mitigation of climate change: scientific-technical analysis. Cambridge University Press, Cambridge

Yamagata Y, Alexandrov GA (1999) Political implication of defining carbon sinks under the Kyoto Protocal. World Resour Rev 11:346-359

Zheng D, Chen J (2000) Edge effects in fragmented landscapes: a generic model for delineating area of edge influences (D-AEI). Ecol Model 132:175-190

Zheng D, Hunt ER, Running SW (1993) A daily temperature model based on air temperature and precipitation for continental applications. Clim Res 2:183-191

Submitted: June 9, 2004; Accepted: January 6, 2005

Proofs received from author(s): February 13, 2005 